Georgia (published in 1959, with Merritt B. Pound as co-author).

Though Tom's life was punctuated mainly with successes, he also experienced its deepest tragedies, losing both his wife and his daughter to cancer when they were still young. Their photographs adorned his office and his eyes would water whenever he spoke of them. Despite these misfortunes, Tom remained a warm and high-spirited individual, bringing happiness to all who knew him.

From among his many accomplishments, Tom will be best remembered perhaps for his warmth and gracious humanity that he so freely shared with everyone. In this hurry-up age, he took the time to be a friend; he cared deeply about the disadvantaged; and he was keenly devoted to every student who came his way. The memories of this kindly man-lost in thought behind a wall of books or carrying friendship to every corner of the campus-will long endure at the University.

Loch K. Johnson

University of Georgia

\section{Clarence A. Berdahl}

Until his death on September 12, 1989, Clarence A. Berdahl was a source of joy for many different reasons. The way stations of his life do not reflect this adequately: Born on Flag Day in 1890 in Baltic, only seven months after South Dakota became a state, and after attending Augustana College, he received a bachelor's degree from St. Olaf College (1914), a master's degree from the University of South Dakota (1917), a graduate fellowship in political science at the University of Illinois in its 50th year (1917) and three years later his doctorate (the Department's fifth ever), teaching position at the University of Illinois from 1920 until his retirement in 1958 , and, after almost a decade of teaching at Southern Illinois University, a 22-year role as political science Nestor in Urbana-Champaign. Such longevity is of course remarkable (something he attributed to his stern Norwegian upbringing), but what was it that made Clarence so distinctive to so many of us?

For one thing, we knew Clarence as a dedicated scholar who made solid contributions to knowledge in the budding discipline of political science. Such books as War Powers of the Executive in the United States (1921) and The Policy of the United States with Respect to the League of Nations (1932), not to speak of his many articles in scholarly journals, were important in developing the field and, particularly, enhancing the impression among government officials that professional political scientists were to be taken seriously. Late in his formal career he helped write two of the more compelling books published by the political scientists of the time: Toward a More Responsible Two-Party System (1950) and Presidential Nominating Politics in 1952 (1954).

We also knew Clarence for the sense of continuity in the political science discipline that he gave us. It was not merely that he numbered among his close associates and friends such men as John Fairlie, Frederic Ogg, Charles Merriam, and James Garner, but that he had, with them, helped to shape the profession. Younger members of the American Political Science Association may have seen Clarence mainly as the Association's senior in terms of continuous membership-an APSA member since 1917 ! Those of us with more historical interest or recollection will have seen him as a man strongly committed to the profession. For a decade (1923-32) he sat on the editorial board of The American Political Science Review, even acting as managing director in 1923-24; and from 1919 to 1930 provided the Review's readers with a quarterly bibliography, "Recent Publications of Political Interest: Books and Periodicals." His membership on the Association's Research Committee, chaired by Merriam, was only the first of several important assignments, including election to the Council, chairing the Program and APSR Evaluation committees, and serving on the influential Committee on Political Parties.

The University of Illinois knew Clarence, its oldest professor emeritus, as an exemplary academic citizen. Throughout his tenure he gave the University effective leadership, serving on various University committees and chairing the Division of Social Sciences (1935-39) as well as the Department of Political Science (1942-48). World War I saw him leave the University to perform military service. In subsequent years he provided the Department of State with policy analysis on international organizations, the Office of Strategic Services (OSS) through wartime liaison among the Norwegians, British, and Americans, and, in 1945, the United Nations Conference in San Francisco in his role as Assistant Executive Officer. In local politics he generously gave his talents to the Champaign County Democratic Party.

Doubtless most important was Clarence's human warmth. With his devoted wife, Evelyn, who died in 1973 , he offered hospitality to generations of colleagues and students. The latter, particularly, came to treasure him. In fact, after his retirement the Department honored his teaching skills by creating as its top prize the Clarence A. Berdahl Undergraduate Teaching Award. Clarence also gave us a firm linkage between Norwegian and American society. His grandfather's homestead in the Dakotas, after all, had provided Clarence's brother-in-law, O. E. Rölvaag, the basis for Giants in the Earth, the stunning depiction of Norwegian immigrant life in the United States. Clarence's nephew, Karl Fritjof ("Fritz") Rolvaag, became governor of Minnesota. Clarence's ties to the Norwegian communities in the Midwest, visits to Norway, especially the valley of Berdaal whence his family sprang, liaison work during World War II, and, not to be forgotten, participation in the Helmskringla Club at the University of Illinois lent Norwegian-American culture a real presence.

Clarence was proud not to have been sick a day in his life. He played softball until his 80s, hiked until his 90s, appeared in his office every day until summer 1989 , regularly attended social gatherings and concerts at the Krannert Center for the Performing Arts, and talked about politics and political science until his mercifully brief illness. We shall miss him.

Richard L. Merritt

University of Illinois at Urbana-Champaign 